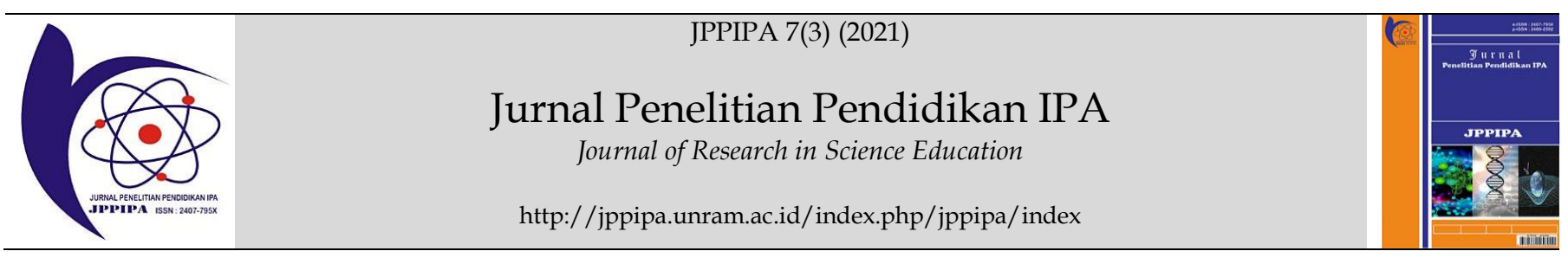

\title{
Analysis of Practicum Skills for Private High School Alumni in Bandung City in Higher Education
}

\author{
Tri Ayu Lestari ${ }^{*}$, Baiq Sri Handayani ${ }^{1}$ \\ ${ }^{1}$ Biology Education Study Program, University of Mataram, Mataram, Indonesia
}

DOI: $\underline{10.29303 / \text { ippipa.v7i3.723 }}$

\section{Article Info}

Received: April 26th, 2021

Revised: June 21 th 2021

Accepted: July 7th, 2021

\begin{abstract}
This study aims to analyze the practical skills possessed by high school alumni to carry out practicum in higher education. The population in this study were high school alumni at universities. The sampling technique used is purposive sampling and snowball sampling. The subjects of this study were high school alumni who entered the faculties of Mathematics and Natural Sciences and Engineering, totaling 46 people. Data collection is done by using questionnaires and interviews. The results showed that as many as $69 \%$ of students found it difficult to carry out practical procedures, $43 \%$ of students found it difficult to follow biology practicum, and 59\% of students found it difficult to use practicum tools. Based on these results, the benefits of the practicum that has been followed in high school on implementing practicum in lectures are a better understanding of the material, knowing how to use tools, and practicum in high school contributing when doing a practicum in lectures.
\end{abstract}

Keywords: Practical Skills; High School Alumni; College

Citation: $\quad$ Lestari, T., \& Handayani, B. (2021). Analysis of Practicum Skills for Private High School Alumni in Bandung City in Higher Education. Jurnal Penelitian Pendidikan IPA, 7(3), 388-394. doi:https://doi.org/10.29303/jppipa.v7i3.723

\section{Introduction}

Practicum is an integral part of science education, especially biology. This is an indication of how important the role of the practicum is in achieving the goals of science education. The existence of practicum is widely supported by learning psychology experts, science experts, and education experts, although each is reviewing from a different side about the benefits of practicum. Research results reported in professional journals in science education and dissertation or thesis abstracts show a positive effect of practicum on science teaching.

Practicum is one factor that influences student learning outcomes, which plays an important role in supporting the success of the science teaching and learning process. Theory and practicum in Natural Science education are inseparable parts. Some learning media experts put forward slogans in the teaching and learning process, namely: "If I hear I forget If I see I remember If I do I understand and I know," which means when I hear I forget when I see I remember if I do I understand and know (Latuhera, 1998).

One of the private high schools in the city of Bandung adopted the development of Information Technology well. This is not balanced with practical activities that should be carried out, especially for science subjects. Inadequate laboratory facilities, the number of laboratories that are only one for all subjects, and a large number of study groups are some of the obstacles that practical activities are not carried out.

Many of these high school students got achievements in various Mathematics and Science competitions and were accepted at various favorite public and private universities. Provision of students as capital for learning in higher education is sufficient in terms of theory but not for practicum. The information obtained is that several alumni still maintain their achievements in both academic and non-academic 
fields. This becomes a big question to what extent the benefits of practicum that should be carried out in high school are for students who will study in college. Based on this description, it is necessary to conduct research on the skills of conducting practicum experiments for private high school alumni in the city of Bandung at universities.

\section{Method}

The population is the entire research subject (Arikunto, 2010). The population in this study was the alumni of the Bandung City Private High School in college. The sampling technique used is purposive sampling and snowball sampling. Purposive sampling is a sampling technique based on certain goals and certain considerations (Arikunto, 2010). The subjects of this study were the alumni of the Bandung City Private High School who entered the Faculty of Mathematics and Natural Sciences and Engineering, totaling 46 people.

Meanwhile, to strengthen the research data results, snowball sampling was also carried out, namely the technique of determining the sample that was initially small in number, then enlarged (Sugiyono, 2013). This sample includes Bandung City Private High School alumni in various universities consisting of Mathematics, Physics, Chemistry, Biology, and Engineering majors. This study uses several types of data collection instruments can be seen in the following Table 1.

Table 1. Types of Instruments Used

\begin{tabular}{|c|c|c|c|c|}
\hline No. & $\begin{array}{l}\text { Instrument } \\
\text { type }\end{array}$ & Technique & Target & Information \\
\hline 1. & Questionnaire & Test & Alumni & $\begin{array}{l}\text { Questionnaires are used as the main instrument to determine the practicum } \\
\text { skills of Bandung City Private SMA alumni when doing a practicum in } \\
\text { lectures. }\end{array}$ \\
\hline \multirow[t]{2}{*}{2.} & \multirow[t]{2}{*}{ Interview Draf } & \multirow[t]{2}{*}{ Nontest } & Teacher & $\begin{array}{l}\text { The teacher interview draft is used as supporting data to find out the } \\
\text { teacher's opinion about the benefits of the practicum carried out in the } \\
\text { learning process. }\end{array}$ \\
\hline & & & Student & $\begin{array}{l}\text { The results of student interviews are used as supporting data to strengthen } \\
\text { student statements in the questionnaire. Student interviews were } \\
\text { conducted with only three people as representatives. }\end{array}$ \\
\hline
\end{tabular}

\section{Result and Discussion}

After collecting data on Bandung City Private High School alumni majoring in Agroindustry, Agrotechnology, Chemical Analyst, Biology, Pharmacy, Physics, Nutrition, Animal Science, Medicine,
Mathematics, Animal Husbandry, and Environmental Engineering, the data was then processed. Data processing results in the form of a percentage. The following are the questionnaire results used to determine the practical skills of private high school alumni in the city of Bandung when attending practicum in lectures.

Table 2: Recapitulation of Student Questionnaire Results

\begin{tabular}{|c|c|c|c|c|c|}
\hline No. & Statement & $\begin{array}{l}\text { Response } \\
\text { (Times) }\end{array}$ & Number & $\begin{array}{l}\text { Total } \\
\text { Number }\end{array}$ & $\begin{array}{c}\text { Persentage } \\
(\%)\end{array}$ \\
\hline \multicolumn{6}{|c|}{ While in Lecture } \\
\hline \multirow[t]{5}{*}{1} & The number of practicums that have been carried out & $1-10$ & 16 & 46 & 35 \\
\hline & during lectures & $11-20$ & 12 & & 26 \\
\hline & & $20-30$ & 9 & & 20 \\
\hline & & $50-60$ & 6 & & 13 \\
\hline & & $>100$ & 3 & & 6 \\
\hline \multirow[t]{7}{*}{2} & Practicums that have been carried out & Many & 11 & 46 & 24 \\
\hline & & Chemistry & 7 & & 15 \\
\hline & & Biology & 14 & & 31 \\
\hline & & Physics & 6 & & 13 \\
\hline & & Kimia \& Biology & 4 & & 9 \\
\hline & & Chemistry \& & 3 & & 6 \\
\hline & & $\begin{array}{l}\text { Physics } \\
\text { Chemistry \& } \\
\text { Physics }\end{array}$ & 1 & & 2 \\
\hline
\end{tabular}




\begin{tabular}{ll}
\hline No. & Statement \\
\hline 3 & Obstacles when doing practicum
\end{tabular}

4 The most difficult practicum to follow

5 Difficulty when using practical tools

6 Difficulty when carrying out practical procedures

7 The skills needed to be able to take part in a practicum in lectures

8 The benefits of practicum that have been followed while in lecture

When in high school

9 Number of practicums that have been done in high school

Practices that have been carried out in high school

11 The most mastered practicum in high school

The benefits of the practicum that has been followed while in high school

13 Contribution of practicum in high school to do a practicum in lectures

14 The relationship between the objectives of the practicum that has been carried out in high school is related to the material and the continuity of the practicum in lectures

\begin{tabular}{|c|c|c|c|}
\hline $\begin{array}{l}\text { Response } \\
\text { (Times) }\end{array}$ & Number & $\begin{array}{l}\text { Total } \\
\text { Number }\end{array}$ & $\begin{array}{c}\text { Persentage } \\
(\%)\end{array}$ \\
\hline None & 6 & 46 & 13 \\
\hline Compile Report & 7 & & 15 \\
\hline Performing & 16 & & 35 \\
\hline Procedure & & & \\
\hline $\begin{array}{l}\text { Use of Tools and } \\
\text { Materials }\end{array}$ & 13 & & 28 \\
\hline Performing & 4 & & 9 \\
\hline Practical Analysis & & & \\
\hline None & 9 & 46 & 20 \\
\hline Biology & 20 & & 43 \\
\hline Biology & 4 & & 9 \\
\hline Physics & 6 & & 13 \\
\hline Chemistry & 7 & & 15 \\
\hline No & 19 & 46 & 41 \\
\hline Yes & 27 & & 59 \\
\hline Yes & 32 & 46 & 69 \\
\hline No & 14 & & 31 \\
\hline Lots & 11 & 46 & 24 \\
\hline Managing time & 5 & & 11 \\
\hline Using tools & 13 & & 28 \\
\hline Procedure & 15 & & 33 \\
\hline Information & 2 & & 4 \\
\hline Lots & 11 & 46 & 24 \\
\hline Theory & 28 & & 61 \\
\hline $\begin{array}{l}\text { Critical and } \\
\text { analytical }\end{array}$ & 5 & & 11 \\
\hline Skilled & 2 & & 4 \\
\hline Lupa & 2 & 46 & 4 \\
\hline 1-3 times & 26 & & 57 \\
\hline 4-6 times & 13 & & 28 \\
\hline$>7$ times & 5 & & 11 \\
\hline Forget & 6 & 46 & 13 \\
\hline Lots & 7 & & 15 \\
\hline Nothing & 1 & & 2 \\
\hline Chemistry, & 27 & & 60 \\
\hline Physics, Biology & & & \\
\hline Chemical Physics & 1 & & 2 \\
\hline Chemistry & 1 & & 2 \\
\hline Biology & 1 & & 2 \\
\hline $\begin{array}{l}\text { Chemistry \& } \\
\text { Biology }\end{array}$ & 2 & & 4 \\
\hline Biology & 22 & 46 & 48 \\
\hline Chemistry & 20 & & 43 \\
\hline Physics & 4 & & 9 \\
\hline Nothing & 9 & 46 & 20 \\
\hline Theory & 27 & & 58 \\
\hline Tool Use & 9 & & 20 \\
\hline $\begin{array}{l}\text { Not confused } \\
\text { when in lecture }\end{array}$ & 1 & & 2 \\
\hline No & 9 & 46 & 20 \\
\hline Yes & 37 & & 80 \\
\hline No & 9 & 46 & 20 \\
\hline Yes & 37 & & 80 \\
\hline
\end{tabular}


Recapitulation of Alumni Questionnaires while in Lecture

The Bandung City Private High School alumni who are currently studying in various majors, especially the Faculty of Mathematics and Natural Sciences, Medicine and Engineering, have done practicum about 1-more than 100 times. The questionnaire netted from 46 high school alumni was $35 \%$ had done practicum 1-10 times, $26 \%$ had done practicum 11-20 times, and as much as $20 \%$ had done practicum 20-30 times. These results were obtained from Bandung City Private High School alumni who had studied for 1-5 semesters.

As many as $13 \%$ of the high school alumni have done the practicum 50-60 times and 6\% have done the practicum more than 100 times. The results are obtained from high school alumni who have studied for 3-5 semesters.

Many practicums have been carried out by 46 alumni of the Bandung City Private High School. The results of the questionnaire showed that the alumni's answers varied so that they were grouped based on science subjects, namely chemistry, physics and biology or a combination of them.

Table 3: Results of Questionnaire Types of Practicum that Have Been Done in Lectures

\begin{tabular}{|c|c|c|}
\hline $\begin{array}{l}\text { Total Percentage } \\
\text { (\%) Alumni }\end{array}$ & $\begin{array}{l}\text { Practical } \\
\text { Subjects }\end{array}$ & Practicum Type \\
\hline 24 & & Lots of practice \\
\hline 15 & Chemistry & $\begin{array}{l}\text { Practicum of basic chemistry, analytical chemistry, environmental laboratory } \\
\text { chemistry and others }\end{array}$ \\
\hline 31 & Biology & $\begin{array}{l}\text { Microbiology practicum, Anatomy, Histology, Physiology, Biochemistry, } \\
\text { Parasitology, Anatomical pathology, Basic biology 1, Plant structure and } \\
\text { development, Animal structure, Basic biology 2, Genetics, Ecology and others }\end{array}$ \\
\hline 13 & Physics & $\begin{array}{l}\text { Practicum on making a scale on a thermometer, Calculating the speed of an } \\
\text { elevator using a person's mass, GLBB, Moment of inertia and others }\end{array}$ \\
\hline 17 & Combined & $\begin{array}{l}\text { Practical basic chemistry, basic physics, basic biology, programming, fluid } \\
\text { mechanics, engineering mathematics, environmental microbiology, environmental } \\
\text { laboratories, physical and chemical processing, biological process engineering, } \\
\text { waste management, and others. }\end{array}$ \\
\hline
\end{tabular}

Alumni of the Bandung City Private High School who experience problems when doing practicum are $87 \%$. As many as $15 \%$ of alumni are constrained in making practicum reports. Alumni who are constrained in the use of tools and practicum materials are $28 \%$. Practical procedures such as memorizing procedures and thoroughness in doing practicum are obstacles for $35 \%$ of alumni. As many as $9 \%$ of alumni are constrained in the analysis stage, distinguishing erythrocytes, leukocytes, and platelets under a microscope.

The practicum was carried out by 46 alumni of the Bandung City Private High School in college, as many as $80 \%$ of the alumni feel difficulties. The practicum is grouped based on the answers to the questionnaire results, namely biology, biologychemistry, physics, and chemistry subjects. As many as $43 \%$ of alumni answered that it was difficult to do practical work related to biology subjects such as anatomy practicum, bacterial isolation, use of microscopes, genetic engineering, and others. 9\% of alumni find it difficult to do practicum related to Biology-Chemistry subjects. As many as $13 \%$ related to physics subjects and 15\% related to chemistry subjects, Bandung City Private SMA alumni felt difficulties such as in environmental laboratory chemistry labs and electrical circuits.

As many as $59 \%$ of the 46 alumni of Bandung City Private High Schools found it difficult to use practical tools. Tools that are difficult to use are microscopes, observation equipment with preparations, titration equipment, and others.

The Bandung City Private High School alumni who find it difficult to carry out practical procedures are $69 \%$. They find it difficult, such as when memorizing material names, formulas, and chemical structures, understanding the stages such as in the planning analysis method practicum module, when looking at the histological picture of the preparations, and so on.

The practicum which has been attended by 46 alumni of the Bandung City Private High School in higher education, requires several skills. Time management skills were answered by $11 \%$ of alumni. Skills in using practical tools were answered by $28 \%$ of alumni. As many as $33 \%$ of alumni answered that they acquired skills related to practical procedures such as taking data carefully and carefully, titration methods, mixing, chemical reactions, dissecting frogs, herbarium, insectarium, and others. As many as $4 \%$ of alumni 
answered that they must convey information well by doing a practicum in lectures.

Practicums that have been carried out in universities in addition to providing skills, also provide benefits for better understanding the material being taught. This was obtained from the answers of $61 \%$ of alumni of the Bandung City Private High School. As many as $11 \%$ of alumni answered that they have become more critical and analytical. As many as $4 \%$ of alumni answered that they became more skilled in using practical equipment.

\section{Alumni Questionnaire Recapitulation while in High School}

As many as 46 alumni of Bandung City Private High School are now studying in various majors, and they have a science background when they were in high school. The questionnaire netted from the alumni of the Bandung City Private High School regarding the number of practicums that have been carried out; as many as $4 \%$ of alumni answered forgot, $57 \%$ of alumni answered 1-3 times, 28\% answered 4-6 times and as many as $11 \%$ answered more than seven times.

At the lecture, the alumni of SMA Swasta Bandung answered the practicum implemented in high school based on Chemistry, Physics, Biology, and its combination. As many as $13 \%$ of alumni answered forgot, $15 \%$ answered a lot, $2 \%$ answered no, $60 \%$ answered Chemistry, Physics and Biology, 2\% answered Physics and Chemistry, 2\% answered Chemistry, 2\% answered Biology, and 4\% answered Chemistry and Biology.

Most alumni mastered the question of practicum while still in high school. A total of $48 \%$ of alumni replied that they mastered the practice of biology. Some alumni mention the title of their biological practicum, such as blood group tests and food tests. A total of $43 \%$ of alumni master chemical practicum such as electrolysis practicum. As many as $9 \%$ of alumni master the practice of physics.

Regarding the benefits of practicum conducted in SMA, as many as $20 \%$ of Bandung City Private SMA alumni answered no. As many as 58\% answered better understand the material, and as much as $20 \%$ know how to use the tool. As many as $2 \%$ answered that the practicum conducted in high school contributed during lectures. $80 \%$ of the 46 alumni of the Bandung City Private High School are of the opinion that the practicum carried out during high school contributes to conducting practicum in higher education.

As many as $80 \%$ of the private SMA alumni are of the opinion that the purpose of the practicum that the SMA has carried out is related to the material and the continuity of the practicum carried out in lectures.
The questionnaire given to alumni contained 14 question points. Questions are used to collect data about the practical skills of Bandung City Private SMA alumni in universities. Based on the results of the questionnaire, the data were analyzed according to the focus of the study and cross-checked with the results of teacher and alumni interviews.

The results of the questionnaire stated that several alumni of the Bandung City Private High School who are now studying in various majors, especially the Faculty of Mathematics and Natural Sciences, Medicine and Engineering, have encountered several obstacles when conducting practicum in Higher Education. The Bandung City Private High School alumni, totaling 46 people, have done practicums from 1 to more than 100 times. The results were obtained from Bandung City Private SMA alumni who had studied for 1 to 5 semesters. The alumni have conducted practicum such as microbiology practicum, anatomy, histology, physiology, biochemistry, parasitology, anatomical pathology, basic biology 1, plant structure and development, animal structure, basic biology 2, genetics, ecology, etc.

As many as $87 \%$ of alumni experience problems when doing a practicum. The things that are difficult for practitioners to follow when practicing are anatomical practicum, bacterial isolation, the use of microscopes, and genetic engineering. Alumni find it difficult in terms of making reports, using practical tools and materials such as using a microscope, observing equipment with preparations, titration equipment and carrying out practical procedures such as memorizing procedures and thoroughness in conducting practicums and analyzing lab results.

The results of interviews with biology teachers in grades X, XI, and XII stated that they used only to do three practicums such as grouping plants, testing blood types, and making biotechnology products out of a minimum of 14 practicums that had to be done in high school. This is the cause of the Bandung City Private High School alumni experiencing problems when doing a practicum in college. These alumni do not have the learning experience and some of the skills they should have acquired in high school.

The obstacle for biology teachers not to do practicum is related to the facilities and infrastructure provided at the school. Bandung City Private High School is located in 3 locations and only has one laboratory which is located on Jalan Diponegoro only. Biology practicum tools and materials available in the laboratory are stacked with other subject practicum tools and materials. Based on the narrative of the class XI biology teacher, sometimes the laboratory is used as a multifunctional place such as to store unused or unused school equipment, for teacher meetings and 
currently because the Bandung City Private High School is in the process of being built, the laboratory is used as the Principal's room and the Human Resource room, and Development (HRD).

How to use the tools and materials used as a provision for alumni to do a practicum in higher education is very limited. Alumni of the Bandung City Private High School get experience related to the use of tools in biology practicum such as loops, blood lancets, and equipment for making biotechnology products. In lectures, alumni are required to be able to use tools such as microscopes, observation equipment using preparations, centrifugation equipment, bacterial isolation equipment, and others. This shows that there is a gap between the lack of experience in using practicum equipment in high school and the demand for mastery of using practicum tools in lectures.

Another factor that causes the practicum cannot be carried out according to the teacher's narrative is the limited time. The Bandung City Private High School developed a national curriculum in collaboration with its specialty as the Taqwa, Intelligent, and Creative Foundation so that there are several lessons for students' moral development such as Tahfidz subjects. The number of lesson hours $(\mathrm{TH})$ for biology subjects is $4 \mathrm{TH}$ for class $\mathrm{X}, 5 \mathrm{TH}$ for class XI and XII, each of which is only 40 minutes. The teacher should use this time as best as possible so that the practicum can be carried out, but the obstacle is the number of school activities that take up learning time, such as Parents Day activities, implementation of private universities, and others.

Practical activities in high school should be the basis for students to do practicum while they are in college. The limiting factor of existing facilities should make teachers more creative in making simple, practical innovations. Most biology teachers do relatively few practical activities because they only depend on available tools and materials. In this regard, biology teachers need to be equipped with knowledge on how to develop an environment-based practicum so that the constraints of inadequate laboratory facilities can be well overcome.

A teacher is important to create a new paradigm to produce best practices in the learning process (Munro, 2005). Without teachers who are able to master teaching materials and teaching-learning strategies, all efforts to improve the quality of education will not achieve optimal results. This means that a teacher is not only expected to be able to master the field of science being taught but also to master teaching and learning strategies such as practicum. The Bandung City Private High School construction is being carried out to complement the existing facilities and infrastructure. Hopefully, it will be a supporter for the implementation of the practicum in the future so that the skills that alumni should have had while in high school can be developed.

Biology does not only discuss the theoretical state of living things but also tries to discuss empirically. This is because biology is a science obtained through scientific work so that in studying biology, two things must be studied, namely product aspects (facts, concepts, principles, theories, laws) and empirical aspects. Practicum and experiments in the laboratory are needed to support biology learning. This is because the practicum method is a form of process skills approach.

A total of 46 alumni of Bandung City Private High School who are now studying in various majors stated that they had carried out practicums from 1 to more than seven times for Chemistry, Physics, and Biology subjects. As many as $48 \% \%$ of alumni answered that they mastered biology practica such as blood type tests and food tests. Regarding the practical benefits that have been implemented in high school, there are $20 \%$ of alumni of Private High School in Bandung answered no. As many as $80 \%$ of alumni say they practice and make them understand the material better, know how to use tools. Practicum conducted in high school contributes when practicing in high school lectures.

The statement of the alumni of the Bandung City Private High School is in line with the statement from the interview with the biology teacher that by doing the practicum, they can train the use of the right tools and materials, as well as help their understanding of the biology material taught in class. In addition, students who have high curiosity can get answers from their real curiosity through the practicum. There are many advantages of implementing practicum, so that practicum must be carried out. The following are the advantages of practicum, which are summarized from the answers to student questionnaires and teacher interviews, namely: (a) Practicum uses activities, direct and concrete experiences. Such activities and experiences attract more students' attention and allow the formation of meaningful abstract concepts; (b) Practical activities are more realistic and meaningful; students work directly with real examples. Students immediately apply their abilities; (c) Students learn directly to apply the principles and steps of problemsolving; and (d) Provide opportunities for student involvement in learning situations so as to generate motivation to learn because learning activities will be tailored to the interests and needs of students.

The practicum that alumni have done while in high school indirectly supports practicum activities in lectures. The success of the implementation of the practicum so that students have the competencies and skills that are expected to be influenced by the teacher and the school. Teachers and schools who have not 
developed practicums in the learning process must start to open up because there are many benefits that can be obtained for students by doing practical activities.

A practicum that has been followed by 46 alumni of Private High School in Bandung requires several skills, namely skills in managing time, skills in using practicum tools, and skills related to practical procedures. The practical procedure in question is to take data carefully, carry out practical procedures well, and convey information well.

Practical activities provide understanding to students when learning about science. Woolnough and Allshop (in Rustaman, 2005) suggest four reasons for the importance of learning through practicum activities namely, it can increase student motivation, develop students' basic skills in experiments, and be used as a means of learning scientific approaches and can support subject matter. The skills obtained from practical activities are process skills such as observing, classifying, interpreting, predicting, asking questions, formulating hypotheses, planning experiments, using tools and materials, applying concepts and communicating and generic skills such as direct and indirect observations, awareness of scale, symbolic language, logical framework, logical consistency, the law of cause and effect and constructing concepts. Process skills are usually developed at the basic education level, such as elementary and junior high schools, while generic skills are developed at the high school and university levels.

According to Utomo and Ruijter (1994 in Parsaoran, 2008), the purpose of the practicum consists of developing 3 skills, namely high cognitive skills, affective skills, and psychomotor skills. Cognitive skills such as training can be understood, integrating theory and applying theory in real life. Affective skills such as learning to plan activities independently, cooperate, and communicate information about their field. Psychomotor skills such as learning to install equipment so that it actually runs, and learning to use certain tools and instruments.

Based on this, there are many skills that high school students should already have so that these students can develop the skills they already have in lectures. At least the skills possessed by the Bandung City Private High School alumni are due to the lack of practical activities carried out. As a result, alumni experience problems or find it difficult to do practicals in lectures.

\section{Conclusion}

Alumni of the Bandung City Private High School experience problems when doing a practicum in lectures, especially in the use of practicum tools, carrying out practicum procedures, and analyzing the results of the practicum. For the benefits of practicums that have been followed in high school to the implementation of practicum in lectures are better understanding of the material, knowing how to use tools and practicum in high school contribute when doing practicum in lectures Then the skills that must be possessed by alumni of Bandung City Private High School to be able to take part in practicum in lectures are skills in using tools, skills in practical procedures, analytical skills and skills in conveying information.

\section{Acknowledgments}

The author would like to thank one of the private high schools in the city of Bandung who has been willing to be asked for data and information from both the foundation, teaching teachers and alumni so that this research can run well.

\section{References}

Arikunto, S. (2010). Prosedur Penelitian Suatu Pendekatan Praktik (Edisi Revisi XIV). Jakarta: PT Rineka Cipta. [Indonesian]

Munro, C.R. (2005). Best Practices in teaching and learning: Challenging current paradigms and redefining their role in education. The College $\begin{array}{llll}\text { Quarterly. } & 8 & \text { (3), } & 1-7 .\end{array}$ http://dx.doi.org/10.25316/IR-336

Parsaoran, T. (2008). Penerapan Metode Praktikum Dalam Meningkatkan Hasil Belajar Kimia Siswa Dalam Pokok Bahasan Asam dan Basa di SMP. Retrieved from:

http:// pascaldaddy512.wordpress.com/2008/12 $107 /$ penelitian- [Indonesian]

Rustaman, N. (2005). Strategi Belajar Mengajar Biologi. IMSTEP: Jurusan Pendidikan Biologi FPMIPA UPI._[Indonesian]

Sugiyono. (2013). Metode Penelitain Pendidikan Pendekatan Kuantitatif, Kualitatif, dan RED. Bandung: Alfabeta. [Indonesian]

Utomo, P. (2009). Pengelolaan Praktikum di Laboratorium Kimia SMA/MA. Makalah pada kegiatan PPM (Pengabdian pada Masyarakat) Kerja sama yang berjudul Pelatihan Pengelolaan Laboratorium Kimia bagi Guru/ Pengelola Laboratorium SMA/MA Kabupaten Bantul. Yogyakarta. [Indonesian] 